\title{
THE NIHA SITES (LEBANON) CULTURAL LANDSCAPE: A 3D MODEL OF SANCTUARIES AND THEIR CONTEXT
}

\author{
J. Yasmine,
}

Associate Professor,

Lebanese University, Institute of Fine Arts, Centre of Restoration \& Conservation, jeanyasmine@gmail.com, mobile: +961 (0)3 661552

KEY WORDS: Cultural landscape, built-up archaeology, 3D model, sanctuary, temple, quarry, Niha, Beqaa

\begin{abstract}
:
The paper aims at presenting the historical sites of Niha (Beqaa valley, Lebanon), their cultural values, and the methodology applied in the assessment of these values through the use of $3 \mathrm{D}$ modelling.

The whole cultural landscape comprises the current village of Niha (altitude 1100m), the archaeological site of Hosn-Niha (altitude $1350 \mathrm{~m}$ ), and the area located between these two sites. Two rural sanctuaries constitute the major archaeological remains present in the landscape: the first, located in the village of Niha, is composed of two roman temples with various archaeological structures; the second is located at the top of an antique settlement $2,5 \mathrm{~km}$ above the village of Niha. This second sanctuary Hosn-Niha, includes two temples, one church, remnants of numerous structures, and remains of an antique village. The cultural and religious values of both these sites are clear. However, questions arise regarding the choice for establishing the sanctuaries in these locations.

The aim of the research is to try to understand the reasons for the various settlements in relationship with the topography and the landscape. The methodology applied in the research addresses two levels: a- The landscape level, and b- the built-up archaeology level.

The global 3D models of both the landscape and the sanctuaries allow us to understand the various relations between the landscape, the sanctuaries and the various archaeological structures. An assessment of the various cultural resources found around the sanctuaries, while considering the reasons for their specific placement in the landscape can shed light on the reasons of these choices.
\end{abstract}

\section{INTRODUCTION}

General investigations on rural sanctuaries of the Roman period in Lebanon were undertaken by the author during his academic curriculum beginning $1998^{*}$. In this context, more than five rural sanctuaries were surveyed (Niha, Hosn-Niha, Faqra, Qsar-Naba, Ain Hersha, Hardine). An analysis of their cultural and archaeological landscape, their architecture, their built-up archaeology, and their history was also undertaken.

It is in this general framework that the sites of Niha (village of Niha and sanctuary / village of Hosn-Niha) were closely studied as a whole. The global cultural landscape of the region surrounding both sites includes many important remains that one would understand from a general landscape perspective.

In order to visualize and to try to understand the relations linking the various structures, a general architectural survey of both sanctuaries and sites was undertaken. However, the scale of the landscape is wider than the architecture of the sanctuaries. Different tools were therefore used to map the structures surrounding the sites at various scales. The software's used for the preparation of the 3D models included: 3DS Max and AutoCAD, both from Autodesk.

Our knowledge in relation to the sacred landscape and the religious values of these sanctuaries is still poor. The aim of this paper is to present the new knowledge on the cultural and

\footnotetext{
* M.A. in archaeology at the L.U., 2002. PhD in archaeology at the University Paris 1 (Pantheon-Sorbonne), 2007. See Yasmine, J. (2006).
}

religious landscape acquired by the analysis of the data set in the 3D model of the landscape surrounding the two Niha sites.

\section{DESCRIPTION OF NIHA SITES}

The sites of Niha are located in a valley in the eastern flank of Mount Lebanon. The valley begins in Mount Sannin descending into the Bekaa Valley (plain valley located between Mount Lebanon and Anti-Lebanon at the border with Syria) in a sinuous manner (Fig. 1).

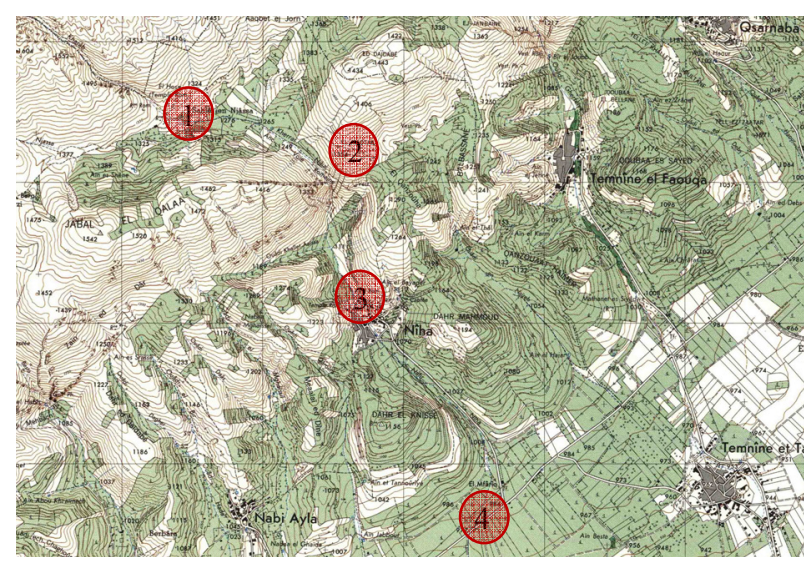

Figure 1. Zahle Map. Scale 1/20,000,

(C) Direction de Affaires Géographiques 
This valley begins with 1- Hosn-Niha (1350m altitude) (Fig. 2) in a corridor facing the Northeast and then goes towards the south-east in the vicinity of $2-$ an ancient quarry $(\sim 1210 \mathrm{~m}$ altitude) (Fig. 3) before moving downstream to 3- Niha ( $1100 \mathrm{~m}$ ) (Fig. 4) and reaches a kilometer away 4- the Beqaa Valley. The latter is a corridor flat lowland oriented Northeast to Southwest. It is $970 \mathrm{~m}$ above sea level and rises to $1050 \mathrm{~m}$ around Baalbek.

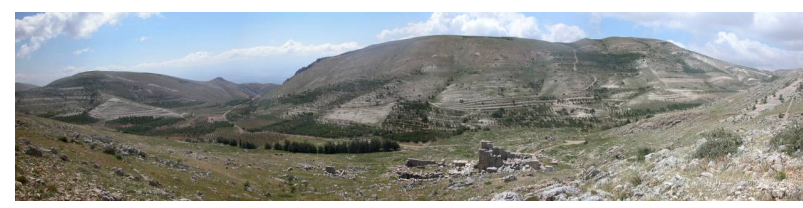

Figure 2. The valley under Hosn-Niha sanctuary and village (C) J. Yasmine; May 2005.

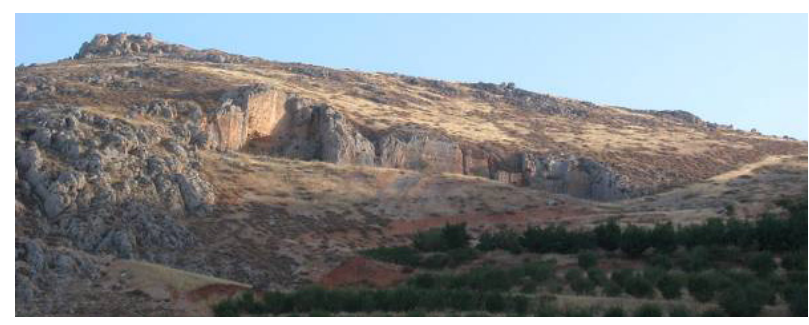

Figure 3. The quarry of Niha. (C) J. Yasmine; May 2005.

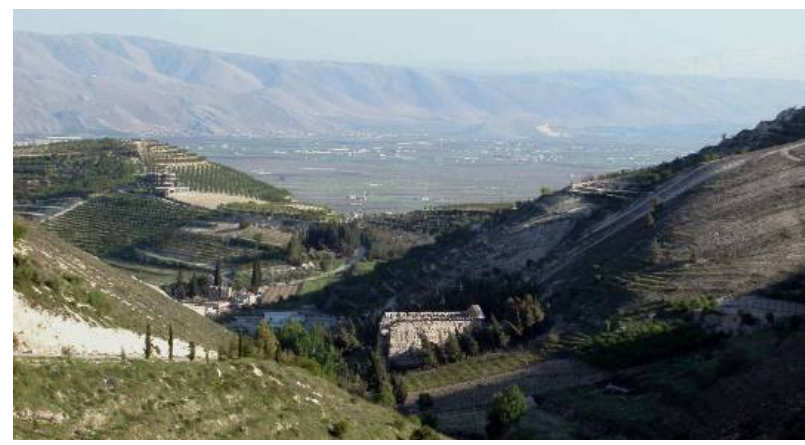

Figure 4. The sanctuary and village of Niha over the Beqaa Valley. (C) J. Yasmine; May 2003.

\subsection{The Hosn-Niha site (Fig. 5).}

The Hosn-Niha site includes many archaeological structures that can be summarized as the following:

- the main sanctuary that comprises one big temple (Temple A), a small one (temple D), a byzantine church, many cult rooms, one constructed spring, all included within a precinct with an entrance located in its east wall;

- a small sanctuary located on a hill to the west of the main sanctuary;

- two big quarries located to the north of the main sanctuary;

- $\quad$ an ancient trade route along the valley;

- the remains of a village to the south of the main sanctuary;

- many blowing springs that are dry in the early summer;

- $\quad$ rock-cut tombs at the village periphery.

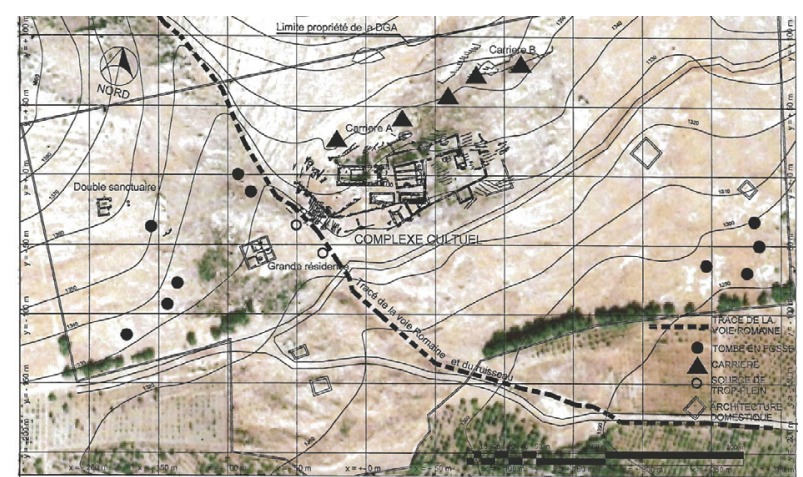

Figure 5. The site of Hosn-Niha and its various remains. Map ( J. Yasmine; January 2007.

The village is surrounded by agricultural fields that are still cultivated today. The ancient trade route runs towards the East and continues towards Niha.

\subsection{The Niha site (Fig. 6).}

The Niha site includes many archaeological and vernacular structures that can be summarized as follows:

- the main sanctuary that comprises one big temple (Temple A), a small one (temple B), a big altar foundation, a very ancient chapel remains, many springs, a big channel draining the ritual water coming from the temples with a built-up cover, all included within a precinct which walls are today destroyed:
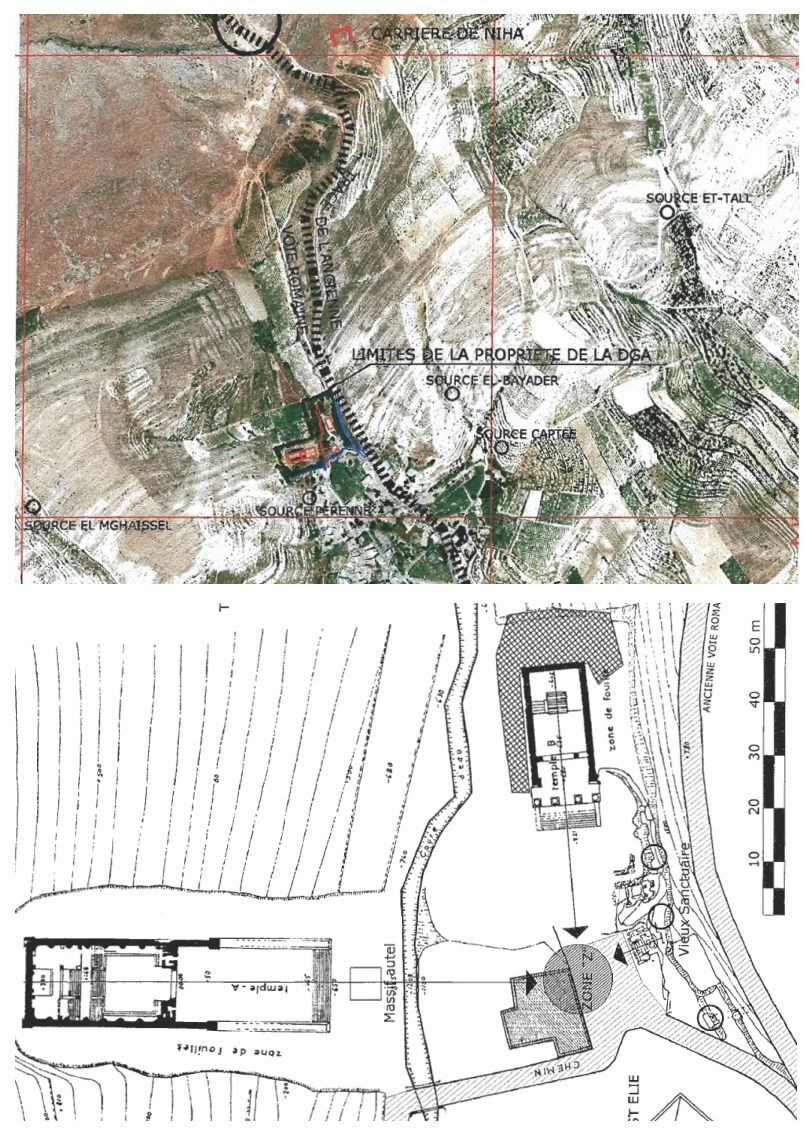

Figure 6. The site of Niha and its various remains.

Basemap (C) DGA; Annotations (C) J. Yasmine; January 2007. 
- a big quarry located $1 \mathrm{~km}$ to the north of the main sanctuary;

- $\quad$ many springs around the sanctuary;

- a vernacular village located to the south of the main sanctuary;

The ancient route arrives to the East of the main sanctuary and follows the modern road.

\section{METHOD APPLIED IN THE PROCESSING OF THE DOCUMENTATION}

The methods applied for documentation utilized the software available at the time of the preparation of the dissertation (i.e. 2002-2005; Cf. Yasmine, J. 2006).

Both sites were documented within the last century. The sanctuaries were surveyed by German archaeologists in the year 1904 (Krencker, D. \& Zschietzschmann, W. 1938, pp. 105137). At the landscape scale, the Directorate of Geographic Affairs of the Lebanese Army documented the whole area by aerial vertical stereo photos means taken with airplanes (photos taken in 1962 - scale $1 / 25,000$; stereographic processing completed in 1963). The produced maps includes contour lines (one each 5m), and various relevant mapping data (Fig. 1)

\subsection{The architectural survey}

At the date of the documentation for the $\mathrm{PhD}$ dissertation, some parts of the sanctuaries had already been documented by the Directorate General of Antiquities (DGA).. The survey was composed following these steps:

1. sketches of the in-situ structures were done;

2. traditional topographic survey (Electronic distance measurer-EDM) of these structures was undertaken;

3. sketches of all scattered blocs were undertaken (at $1 / 100$ scale - Fig. 7 - and at $1 / 20$ scale for selected representative blocs);

4. design of all surveys on AutoCAD;

5. preparation of $3 \mathrm{D}$ model of the temples and the sanctuaries on 3DS Max (Fig. 8, 13, 15 \& 16);

6. virtual reconstruction of the temples using the scattered blocs surveyed (reconstructed blocs in white while in-situ blocs were in sepia; Fig. 9);

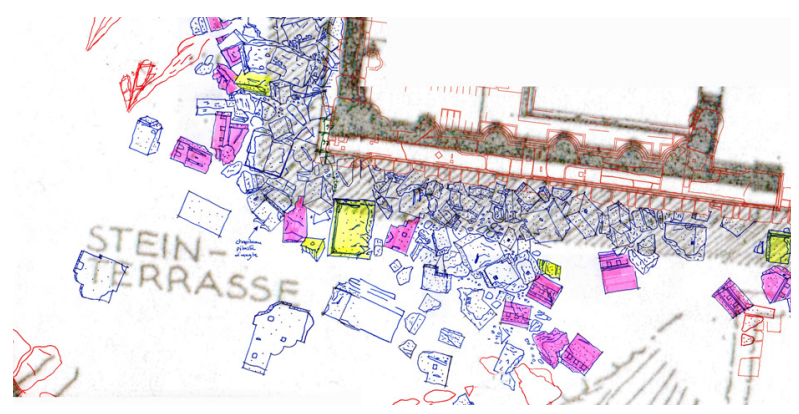

Figure 7. Sketches of scattered blocks.

In red, the EDM survey; in blue the sketches; in yellow and purple, the inventoried blocks. (C) J. Yasmine; 2003.

For elevation surveys, Photomodeler software edited by EOS was utilized to process, through photogrammetric means, the elevations of free standing archaeological structures.
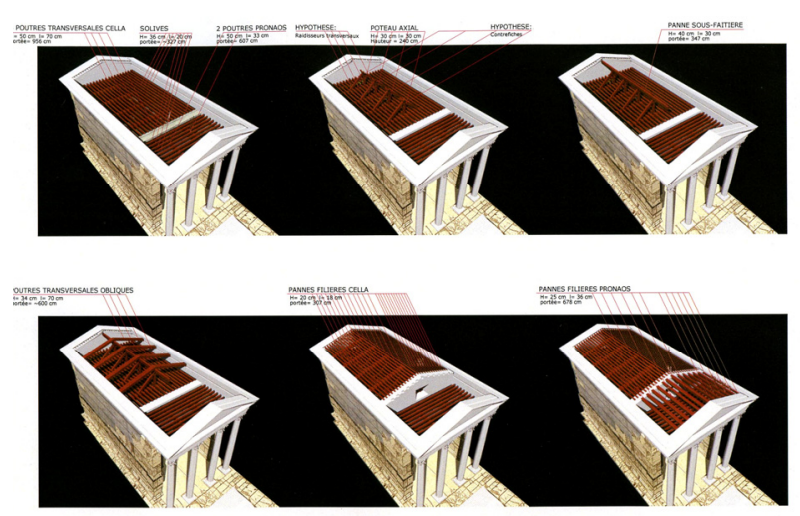

Figure 8. Architectural 3D model of the temple A of Hosn-Niha. C J. Yasmine; 2005.

The virtual reconstruction was made at two scales: the temple scale (one unique building), and the sanctuary scale (a complex compound of many buildings).

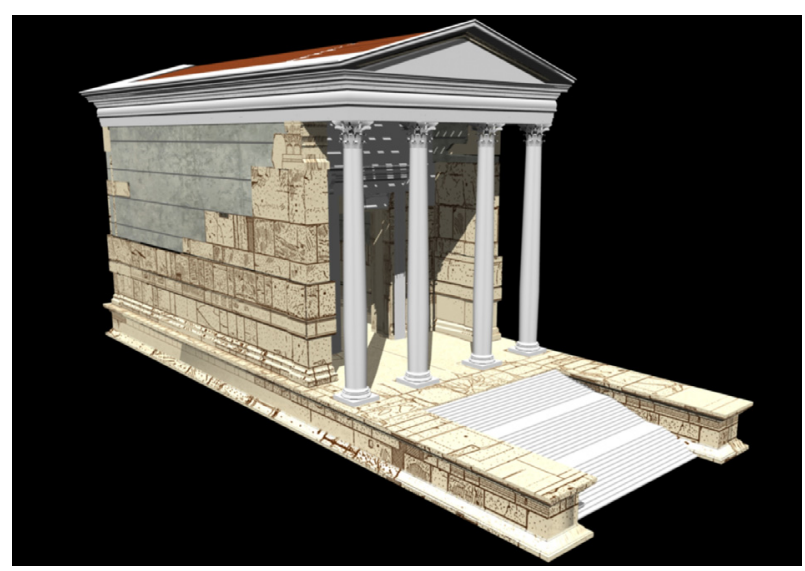

Figure 9. Architectural 3D model of the temple A of Hosn-Niha. (C) J. Yasmine; 2005.

\subsection{The landscape survey}

The survey of the valley surrounding Hosn-Niha was made possible due to the presence of hills surrounding the valley. During the architectural survey, control ground points were surveyed on the landscape scale (with the usage of an EDM).

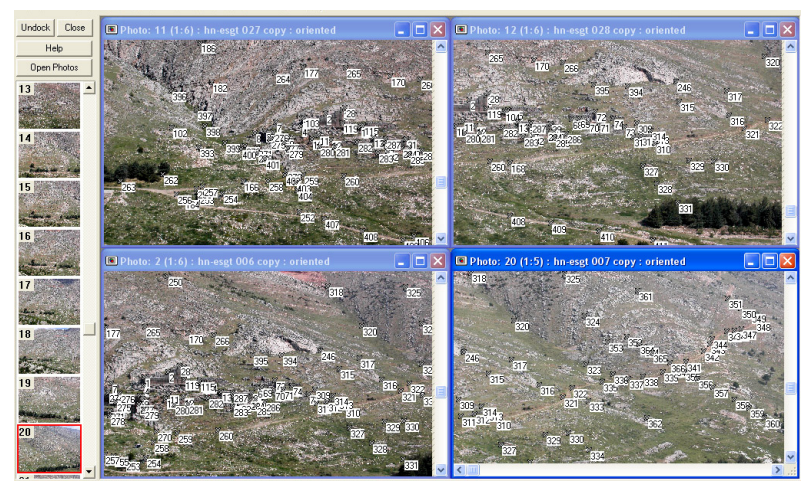

Figure 10. The Photomodeler project to survey with accuracy features in Hosn-Niha landscape. (C) J. Yasmine; 2005. 
In the second phase, photos of the valley were taken from various high points located on the hills surrounding the valley with a calibrated lens using Coolpix 5000 Nikon. These photos were utilized to process a photogrammetric project with Photomodeler (Fig. 10). This last project enabled the location of specific structures in the landscape in a precise way. These features were related to the construction site (the quarry, the stone transportation paths, the retaining walls) or to the main archaeological remains (the rock-cut tombs, the village residences, the springs and the paths, etc.).

For the generation of the Digital Elevation Model (DEM) between Niha and Hosn-Niha, the contour lines of the 1/20,000 maps were utilized in order to prepare a mesh. This was made possible with the help of draftsmen who had to 1- digitize the contour lines using AutoCAD, 2- put each contour line at its specific altitude, and 3-generate the mesh using 3DS Max. At that time, no Google Earth imagery was available online. A local Lebanese mapping firm (GIS Transport) provided satellite imagery (IKONOS imagery) with the authorization to utilize it. This imagery was then projected on the DEM in order to generate the Terrain model (Fig. 11). Fine tuning was possible thanks to the identification of some features on the ground compared with those present in the 1/20,000 map.

Only then was it possible to visualize the whole landscape with 3DS Max in order to understand the various relations linking the archaeological remains in the site.

\subsection{The integration of architectural and landscape surveys}

All the above method applied for the generation of the landscape model is relevant to an architect approach. The goal of this approach is the integration of the architectural $3 \mathrm{D}$ models with all virtual reconstructions in the landscape model. For Hosn-Niha, the whole sanctuary was integrated in the landscape model (Fig. 11). For Niha, the two temples were also integrated in the model. 3DS Max was utilized for the integration process. Basic elements of the landscape were also identified in the whole model in order to put them in relation with both the sanctuaries.

\section{SOME IMPORTANT RESULTS OF THE APPLIED METHOD}

Major findings were obtained as a result of the applied method. First, reasons for the site construction and organisation were clarified. Second, reasons of the implantation of the sanctuaries in relation with the villages were also put in light. Finally, the relationship that links the ancient road, the stream going down to the Beqaa valley, the villages, and the sanctuaries were also addressed thanks to the usage of the 3D model of the whole sites. Another aspect utilized in this model was its ability to process a dynamic model for the various phases of the sanctuary transformation throughout History.

\subsection{The relations between the various archaeological structures}

One of the major results of the applied method was the understanding of the relations that link the various archaeological structures in the topography. The major feature that acts as the heart of the sanctuary is the former focal point to which all the sacred buildings are visually oriented.

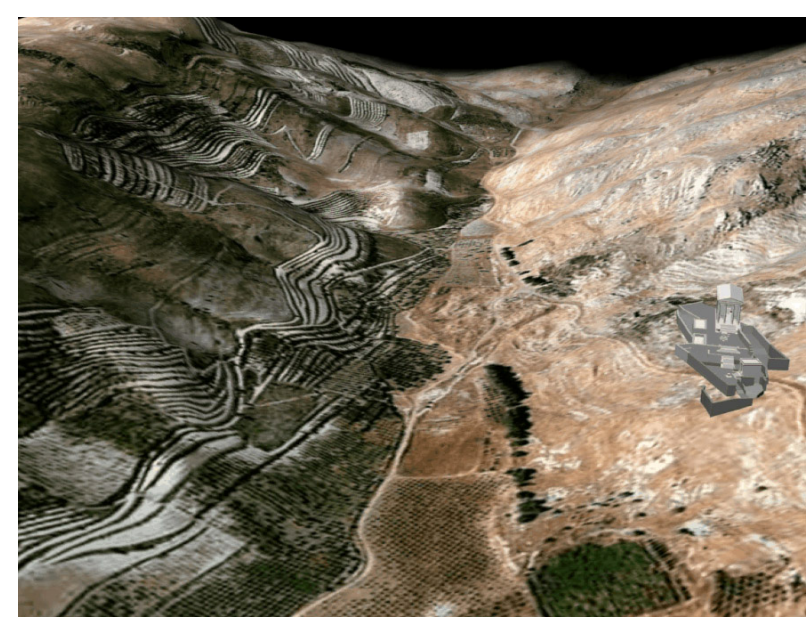

Figure 11. The Terrain model with the integration of the Hosn-Niha sanctuary. C J. Yasmine; 2005.

In both sanctuaries, the area facing the oldest temple is the location of the first altar / sacred zone to which the people used to face when undertaking their rites. The various successive temples are all visually oriented toward this sacred area.

Another very interesting result is the relations that link the quarries with the site of construction of the sanctuaries. In the case of Hosn-Niha sanctuary, the geologic stratification of the area to the north of the temples ensures the presence of natural smooth slopes used as a path for the supply of stones from the quarry to the construction site. At the same time, part of the quarry was used to supply, in-situ, stones used for the retaining walls. In the case of Niha, the quarry is located at a distance of $1 \mathrm{~km}$ to the North of the sanctuary, at an altitude of $1210 \mathrm{~m}$. The slope leading to the site construction follows the old Roman road and has a slope of $10 \%$. It can therefore be easily utilized for the supply of stones.

For the urban setting of Hosn-Niha, one can easily understand the implementation of the village under the sanctuaries, these last being always located on hills close to the sky, the normal house of gods. The rock-cut tombs are also located in the rocky zones at the periphery of the village. The various springs are located along the Roman route at the centre of the village, and can therefore be easily accessible by the inhabitants. In Niha, the modern village superimposes the antique one. Here also, the sanctuary is located on the higher point of the village. It is surrounded by many springs that spurt the water around the various temples. Many archaeological channels drain the spring water towards the temple altars.

\subsection{Understanding the location choice for construction}

The settlement of both site inhabitants in the village and the choice of the precise location of the sanctuaries was one of the major questions raised during the search. It was clear even prior to the $3 \mathrm{D}$ modelling, that the very heart of the sanctuary grew around a sacred area in which the very first image of the god was adored. The early altar stood in the same area.

This area was understandably chosen for the presence of springs in the natural landscape, for water is sacred to the local inhabitants of a desert environment. The sanctuary also needed to be constructed on a high point overlooking the surrounding landscape. For this reason, the builders chose a location that fulfils these requirements. One must not forget the need of stones for the construction process. The presence of a quarry in the very close environment was therefore of utmost importance. 


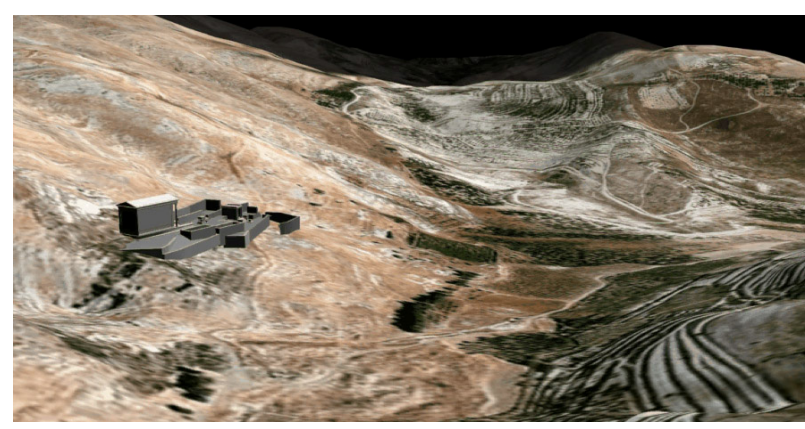

Figure 12. The Terrain model with the integration of the HosnNiha sanctuary in the landscape model: sanctuary overlooking the village. (C) J. Yasmine; 2005.

These aspects that explain the localization of the landscape features were put into light with the aid of the 3D model provided at both the landscape and architectural level (Fig. 12).

\section{THE TRANSFORMATION OF A SANCTUARY THROUGHOUT HISTORY}

Following the archaeological and architectural analysis of the remains, it was possible to propose a hypothetical reconstruction of the sanctuary and its transformation throughout history. The 3D integrated model helped to confirm or invalidate the various hypotheses. The showcase developed below is the one of the Hosn-Niha sanctuary ${ }^{\dagger}$.

\subsection{Hosn-Niha in the $1^{\text {st }}$ century: the birth}

The birth of the Hosn-Niha site and sanctuary can be explained with the presence of blowing springs in the upper part of the village, around the sanctuary. The ancient roman route (via romana) is located in the middle of three or four blowing springs that spurt during snowmelt. The builders chose a high point for the sanctuary, near the geologic stratification proper to be used as a quarry. They bore a well to capture the water of the surrounding springs and placed it in the centre of the very first sanctuary (Fig. 13). At that time, the sanctuary was located directly under the biggest quarry located to the north. The main elevation of the temple was opened towards the core of the $1^{\text {st }}$ village located underneath.

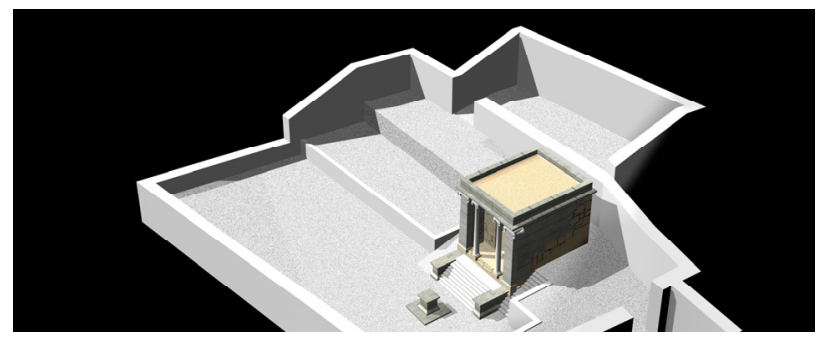

Figure 13. The architectural 3D model of the $1^{\text {st }}$ sanctuary of Hosn-Niha. (C) J. Yasmine; 2005.

The site of Niha did not provide sufficient authentic archaeological remains for a scientific analysis of the successive transformations. Only architectural remains of the temples provided evidence of the transformation. See in this regard Yasmine, J. (2009), pp. 141-146.

\subsection{Hosn-Niha in the $2^{\text {nd }}$ century: monumental} transformation

During the $2^{\text {nd }}$ century AD, the wealth of the Roman Empire and its local representative in Baalbek and Berytus initiated important imperial projects in the various colonies of the Levant. Hosn-Niha was among the chosen sites that underwent such projects. In our case, the builders chose a new location for the quarry located to the west of the first. A huge platform was erected over which they built the new roman style temple (Fig. 14). The new temple overlooks and faces the old altar and well of the former sanctuary (Fig. 15). At the same time, its main façade is opened towards the new extension of the village following urban planning guidelines as given by Vitruvius (Vitruvius, Book III, Chapter 7). 3D model of the landscape confirms these characteristics of the sanctuary vis-à-vis the village.

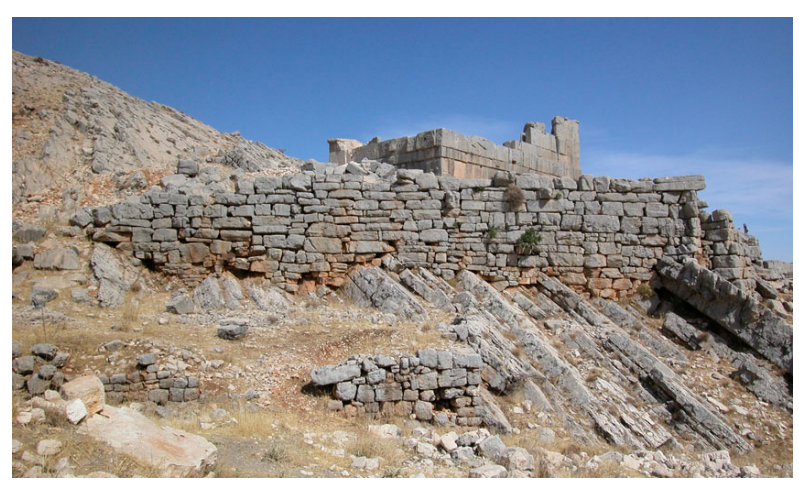

Figure 14. The wall retaining the new platform housing the $2^{\text {nd }}$ century temple of Hosn-Niha. (C) J. Yasmine; 2003.

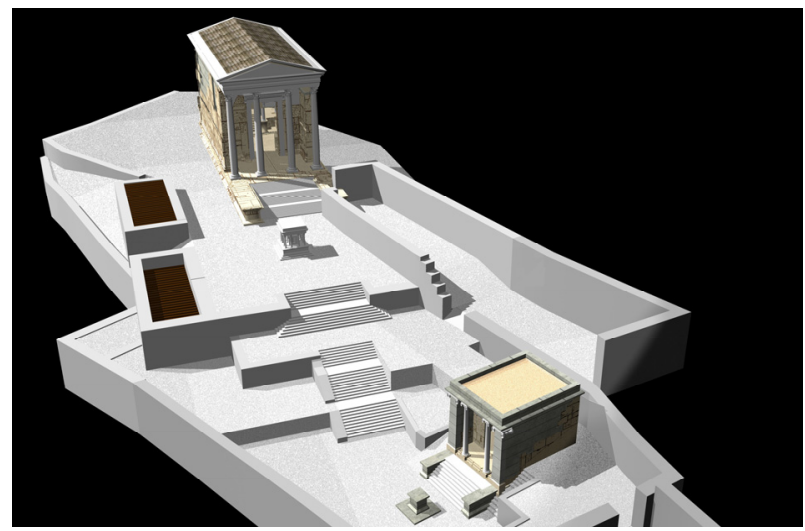

Figure 15. The architectural 3D model of the $2^{\text {nd }}$ sanctuary of Hosn-Niha. C J. Yasmine; 2005.

5.3 Hosn-Niha in the $5^{\text {th }} / 6^{\text {th }}$ century: destruction of the temple and construction of the church.

Strong earthquakes shook the Levant between the $3^{\text {rd }}$ and the $6^{\text {th }}$ century. It is likely that temple A of Hosn-Niha was partially destroyed at that time. The courtyard facing temple A was used for the construction of the new church after the rise of Christianity. The architectural survey of the Byzantine church revealed the reuse of the temple blocs in the construction of the

$\$$ Baalbek and Berytus were the two most important Roman colonies of the Levant. 
church foundations. Other blocs were cut into the old big stones of the temple or taken from the close quarry.

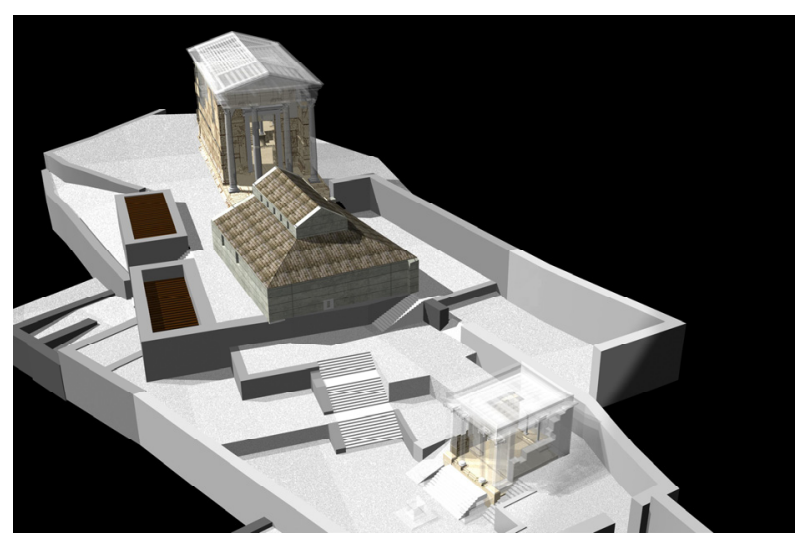

Figure 16. The architectural 3D model of the

Byzantine church surrounded by the two destroyed temples of Hosn-Niha. (C) J. Yasmine; 2005.

The 3D architectural model of the last state of the sanctuary (Fig. 16) as rendered by 3DS Max uses transparent walls / ceilings indicating the shape of the destroyed parts.

\section{CONCLUSION}

The method adopted in the analysis of both architecture and landscape of the sites of Niha provides interesting results for the archaeology of the place.

The 3D integrated model of the landscape provides important explanations for the reasons behind the implantation of the various structures in their precise location. It also provides evidence of the relationships linking these structures. It explains how the builders utilized the site resources in the construction process. It gives some hints on the planning purposes of the inhabitants in locating the sanctuary in the village in relationship with the springs, the wells and the routes.

Finally, this method provides an important tool for the visualization of the sites throughout History. The architectural transformation of the sanctuary can be easily presented in the framework of a didactic environment (school, website or tourist visitor's centre).

\section{REFERENCES}

Aston, M. 1997. Interpreting the landscape: Landscape archaeology and local history, Routledge (London \& New York)

Bender, B. \& Hamilton, S.\& Tilley, Y. 2007. Stone worlds: Narrative and reflexivity in landscape archaeology, Left Coast Press.

Dentzer, J.-M. 1989. Le sanctuaire syrien, in J.-M. Dentzer et W. Orthmann, Histoire et archéologie de la Syrie, t.2, La Syrie de l'époque achéménide à l'avènement de l'Islam, Saarebrücker, pp. 297-322.
Dubertret, L. 1953. Carte géologique au $50000^{e}$; Feuille de Zahlé, Ministère des travaux publics, Beyrouth.

Krencker, D. \& Zschietzschmann, W. 1938. Römische tempel in Syrien, Berlin.

Nordiguian, L. 2005. Temples de l'époque romaine au Liban, Beyrouth.

Vitruvius, Les dix livres de l'architecture, translation Perrault, 1684, Paris.

Walsh, K., (1999) Mediterranean landscape archaeology and environmental reconstruction. In Environmental reconstruction in Mediterranean landscape archaeology, Oxbow Books, 1999, pp. 1-8.

Witcher, R. E. 2012. That from a long way off look like farms': the classification of Roman rural sites in Comparative issues in the archaeology of the Roman rural landscape. Site classification between survey, excavation and historical categories. Edited by Attema, P. \& Schörner, G. Suppl. no. 88 to Journal of Roman Archaeology, pp. 11-30

Yasmine, J. (2006). Complexes cultuels ruraux d'époque romaine dans la Beqaa. Le cas de Hosn-Niha. Problèmes d'architecture et d'archéologie, $\mathrm{PhD}$ dissertation, Université Paris-I, Paris.

Yasmine, J. (2007). Remaniement de temples d'époque romaine; les cas de Niha et de Faqra. Apport de la métrologie. In $B A A L$ 9, 2007, Beyrouth, pp. 301-316.

Yasmine, J. (2009). Transformations monumentales de sanctuaires et de temples antiques. Les cas de Niha et de Hardine. In Topoi 16, 2009, Lyon, pp. 121-152.

Zangger, E., Timpson, M., Yazvenko, B., and Leiermann, H. (1999) Searching for the ports of Troy. In Environmental reconstruction in Mediterranean landscape archaeology, Oxbow Books, 1999, pp. 89-103. 